\title{
MANAGEMENT ACCOUNTING PRACTICES IN NEPALESE CO-OPERATIVE ORGANIZATIONS
}

\author{
Mukti Prasad Neupane *
}

\begin{abstract}
Management accounting is concerned with providing both financial and non-financial information that will help decisions. An understanding of accounting therefore requires an understanding of the decisionmaking process and an awareness of the users of accounting. The major objective of the study will be to examine the Management accounting practices among Nepalese co-operative organizations. While analyzing the application of management accounting tools practiced in Nepalese co-operative organization for planning, controlling and decision making, it was found that Ratio Analysis, Cash flow statement and capital Budgeting are widely practiced representing. All the co-operative organizations of Nawalpur distirict a number of co-operative have been considered as the total population. Till this date there are organizations in Nawalpur in existence. To make the research more reliable, 21 co-operative organizations has been considered for sample population. In average, two techniques were practiced to measure and control overall performance of Nepalese co-operative organization at the end of the year. It seems that $57.15 \%$ Nepalese cooperative organization used below average no. of year ending overall performance measuring and controlling techniques.
\end{abstract}

Key words: Accounting practices, Co-operative, Ratio Analysis, Cash Flow Statement, Capital Budgeting

\section{Background of the Study}

Management accounting is the process of identifying, measuring, analyzing, interpreting and communicating information for searching the goals of the company. Managerial accounting is an integral part of the management process and managerial accountants are important strategic partners in the company's management team (Hilton, 2010:16).

Management accounting is concerned with providing both financial and non-financial information that will help decisions. An understanding of accounting therefore requires an understanding of the decision-making process and an awareness of the users of accounting (Drury, 2011:18).

Management accounting is the term used to describe the accounting methods, systems and techniques, which coupled with special knowledge and ability, assist management in minimizing losses. It is essentially the application of management principles and technical know-how to the planer, development, execution and control of corporate plans (Batty, 2009:2).

A business enterprise today operates in dynamic environment, which involves many new forms of management problem. Due to the complex environment management has to carry out its basic functions of cost minimization and maximization of profit in an atmosphere of uncertainty. The old technique of management by inspection is no longer considered dependable in a situation in which the modern management has realized that even slight error on policy decision may mean either losing a lot of business opportunities or going out of competition. A second chance may not come or even if it does, it may be costly or risky. It therefore, constantly strives to reduce the risk of mistakes in decision-making by keeping abreast of such quantitative information, which would help analyze its administration action in order to reach judicious decisions. It is here that accounting is of importance. Management, therefore, constantly strives to reduce the risk of making mistakes by looking for and analyzing relevant information by

\footnotetext{
* Mr. Neupane is an Associate Professor of Madhyabindu Multiple Campus
} 
means which it hopes to take judicious decision and direct the administration in a better manner (Shrestha, 2007).

The whole idea of managerial accounting is to assist strategic managers to perform management functions more effectively by providing relevant economic information. Management is the process of planning, decision making and controlling. An organization is the process of planning, where different physical resources people and activities get managed by the system force. It is an integrative function directed towards achieving organizational goals it is the management, which plans, decides, implements, and has a control over different activities of the organization (Bajracharya, Ojha, Goet\& Sharma, 2009).

This study is concerned with management accounting practices in Nepalese co-operative organization.

\section{Statement of the Problem}

The co-operative organizations have been operating well from their very beginning of the establishment. The expansion of co-operative business is increasing which indicates the increasing number of co-operative in Nepal. As a result, Nepalese cooperative organizations are competing to transact cooperative business with each other to a large extent. This development has created major challenges for co-operative organizations. In terms of providing services to their clients and maximizing welfare.

Well management and planning are the key tools to achieve the determined goal of any business organization for that Management Accounting provides the techniques to aid the management functions. It gives the proper and necessary information and guidelines to the manager for planning and decision making. Hence, the business complexity can be changed into opportunity by using various tools and techniques of management accounting.

The research questions will help to study the scenarios of management accounting tools being used in co-operative organizations.
1. Which Management Accounting tools are mostly practiced in co-operative organizations?

2. What are the areas where Management Accounting tools can be applied to strengthen the cooperative activities?

3. What are the major difficulties in the application and implementation of Management Accounting tools?

4. What are the regularity provisions regarding existing management tools in Nepalese cooperative organizations?

5. How effective \& efficient is the management accounting system of co-operatives of Nepal?

\section{Objective of the study}

The major objective of the study will be to examine the Management accounting practices among Nepalese co-operative organizations. How the Nepalese co-operative organizations are practicing various management accounting tools for the study.

1. To analyze the present practice of Management Accounting tools used in the co-operative organizations of Nepal.

2. To examine the regulatory provision regarding existing management tools in Nepalese co-operative organizations.

\section{Significance of the Study}

The research work was carried to study the practice of Management Accounting tools used in co-operative organizations of Nepal. This study is significant in the following points.

1. It helps to analyze the use of Management Accounting tools in co-operative organizations. 
30 The Journal of Madhyabindu Multiple Campus, Vol. 6, No. 1, 2021

2. It exploresproblems and potentialities of the co-operative business.

3. It provides information on the application of tools under different situations and encourages the use of Management Accounting tools in planning and decision making.

4. It provides literature to the researcher who wants to carry on further research on this field.

5. This study provides required information to co-operative organizations decision makers, manager, shareholder, other investors, government, researcher, students and stakeholders.

\section{Limitations of the Study}

The study is not free from some of the limitations and constraints. The main limitations are be as follows: -

1. The time frame and resources are constrained in this field.

2. This study focused on Management Accounting practice of only 21 co-operative organizations and didn't consider the other aspects of the co-operative organizations.

3. The study focused on the co-operative organization. Thus, findings might not be applicable to other sectors.

4. The researchwas based on the primary data. So, it is not free from the limitations of primary data.

\section{Review of Literature}

Accounting means the process of analyzing financial transactions and recording them in the book of account to show the financial results of operations. It is the eye of the business which shows a path to go ahead. It has rightly been termed as the language of the business. It communicates the result of business operations to the various parties who have some stake on the business. The objective of accounting is to provide sufficient information to meet the need of various users at the lowest possible cost. As such, the accounts/accounting should aim to provide the right information to the right user/people in the right quality at the right time and at minimum cost.

The term system refers to "An assembly of methods; procedures of techniques that are united by regulated interaction to form an organized whole." In fact, system means a collection of things interacting and inter- dependent to form a complex whole.

A system receives inputs as men, materials, money and machines and so on. Processes them, and generates such outputs as finished products or services. The system model of an entity is drawn in the above figure. Management accounting system is a "resource of management that supplies financial information at all levels to be used in planning and administrating the business." Accounting system has expanded from its traditional confines of historical transaction data to the analysis of present situation and forecasting the future prospects.

Management Accounting is the presentation of accounting information to formulate policies to be adopted by the management and assist its day-to day activities. It helps the management to perform all its function including planning, organizing, staffing, directing and control. It presents to management the accounting information in the form of processed data which it collects form financial accounting (Paul, 2004:1).

The role of managerial accounting now is very different from that of decade of ago. In the past it operates in a strictly staff capacity but now it serves as internal source of business consultants. In many organizations, managerial accountants take on leadership roles in their teams and are sought out for the valuable information they provide. Therefore, the goal of learning managerial accounting is not to be an 
accountant, rather it aims to produce confident entrepreneurs and capable (Bajracharya, et al., 2009)

\section{Review of the Previous Studies}

Only few researches were made in the area of management accounting practice in Nepalese context. However, many other researchers were made in the area of profit planning and control in Nepalese context. As profit planning and control covers some of the aspects of management accounting. Some relevant researches, which have submitted on Management Accounting Practices in the context of Nepal, were selected for review.

Sharma (2011) has conducted a research work on "Management Accounting Practices in listed companies of Nepal." He has focused his study to examine and study the practice of management accounting tools in the listed companies of Nepal. Mr. Sharma's research is based on primary data. Stratified random sampling with proportionate allocation of percentage is followed to draw the sample. In his study, he conclude that: different types of management accounting tools, which are thought in the colleges are not found applied by listed companies of Nepal.Management accounting is to managers in overall managerial activities by providing information and helping in planning, controlling and decisionmaking.Nepalese listed companies are in infant stage in practicing of management accounting tools such as capital budgeting, annual budgeting, cash flow statement, ratio analysis, zero based budgeting; activity-based costing, target costing and value engineering. As Nepal is proceeding towards globalization and has get the membership of WTO, companies are commended to apply management accounting tool to fit with the global environment.

Neupane (2018) has conducted a research entitled "management accounting practice in joint venture banks of Nepal". He has focused his study to examine and study the practice of management accounting tools in joint venture banks of Nepal. Mr. karki's research is based on primary data. In his study he has pointed out various findings and recommendation. Of them some remarkable conclusions are:Capital budgeting, cash flow statement, ratio analysis and annual budget are widely practiced in Nepalese joint venture banks.Profitability index and Net present Value are mostly practiced while purchasing fixed assets, and making long-term investment decision. The main difficulties of not practicing MA in Nepalese joint venture banks are lack of information, lack of cognizance about the tools and lack of expertise.To overcome those difficulties, he has recommended that, the managers of different banks and knowledge us academicians should jointly bring the tools and techniques into light through different media.

\section{Research Methodology}

\section{Research Design}

A research design is specification of methods and procedure for acquiring the information needed. It is the overall operational pattern of framework of the project that stipulates what information is to be collected, from which sources by what procedure. It ensures that information obtained is relevant to the research questions and that it is collected by objective and economical procedures. As per the nature of study, survey research design had been followed with descriptive and analytical approach.

\section{Source of Data}

Data were mainly collected from primary sources. Primary data are collected through questionnaire, interview and discussion.

\section{Population and Sampling}

All the co-operative organizations of Nawalpurdistirict a number of co-operative have been considered as the total population. Till this date there are organizations in Nawalpur in existence. To make the research more reliable, 21 co-operative organizations has been considered for sample population.

\section{Data Collection Procedure}

The study is mainly based on primary sources of data, information collected by developing 


\section{The Journal of Madhyabindu Multiple Campus, Vol. 6, No. 1, 2021}

a structured question and distributing it to the manager and financial controller of co-operative organizations. Altogether fifteen questions were included for study. thirteen questions of them were 'tick mark' and two were open-end questions. To get reliable information, needed discussion had also held with managers and financial controllers.

\section{Data Processing Procedure}

Data collected information from questionnaires was in raw form. The data are tabulated into various tables according to the subject's requirement. Performing of data has simple arithmetic percentage tool is used for analysis. Major findings are based on the analysis and the interpretation of data.

\section{Data Analysis}

Data analyzing is to change it form an unprocessed from to an understandable presentation. So, the analysis of data consists of organizing, tabulating, performing statistical analysis and drawing inferences. Hence data have been processed, organized, tabulated and presented in suitable form. Excel program was used for analysis of raw data which is collected from questionnaires. Appropriate financial, accounting and statistical tools and techniques have been applied.

A percentage is the number of hundredth parts one number is of another. This is the simplest statistical device used in the interpretation of phenomenon. Percentages are recorded to one decimal place. In some case to grasp the relationships percentages are shown.

\section{Management Accounting Tools Practiced in Nepalese Co-operative Organizations}

Table 1

\begin{tabular}{|c|c|c|c|c|}
\hline S.N. & $\begin{array}{c}\text { Management } \\
\text { Accounting Tools }\end{array}$ & No.of Sample & $\begin{array}{c}\text { No. of } \\
\text { Practicing }\end{array}$ & Percentage (\%) \\
\hline 1 & CVP Analysis & 21 & 5 & 23.81 \\
\hline 2 & $\begin{array}{c}\text { Responsibility } \\
\text { Accounting }\end{array}$ & 21 & 6 & 28.57 \\
\hline 3 & Capital Budgeting & 21 & 10 & 47.62 \\
\hline 4 & Ratio Analysis & 21 & 15 & 71.43 \\
\hline 5 & Cash Flow Analysis & 21 & 14 & 66.67 \\
\hline 6 & Standard Costing & 21 & 1 & 4.76 \\
\hline 7 & Zero Base Budgeting & 21 & 1 & 4.76 \\
\hline 8 & Flexible Budgeting & 21 & 4 & 19.05 \\
\hline
\end{tabular}

The Table No 1 demonstrate management accounting tools practiced in Co-operative Organization of Nepal. It is revealed that, 71.43 percent of Nepalese Co-operative Organizations used ratio analysis. Cash flow analysis was practiced $66.67 \%$ of them and Capital Budgeting technique was practiced by 47.62 . Similarly, $28.57 \%$ of them used responsibility accounting and $23.81 \%$ used Cost-volume-profit analysis. The Co-operative organizations practicing flexible budgeting represented 19.05 percent and only
$4.76 \%$ of them used standard costing and zero base budgeting.

\section{Number of Nepalese Co-operative Organizations Practicing One or More Management Accounting Tools}

In Nepal there are some co-operative organizations which practicing more than one anagement accounting tools and some organizations used only one tools which shown in below: 
Table 2

\begin{tabular}{|c|c|c|c|}
\hline \multirow{2}{*}{$\begin{array}{c}\text { Number of } \\
\text { Management } \\
\text { Accounting Tools (x) }\end{array}$} & \multicolumn{2}{|c|}{ Cooperative Organization } & \multirow{2}{*}{ FX } \\
\cline { 2 - 4 } & Number (F) & Percentage & \\
\hline 0 & 1 & 4.77 & 0 \\
\hline 1 & 5 & 23.81 & 5 \\
\hline 2 & 2 & 9.52 & 21 \\
\hline 3 & 7 & 33.33 & 16 \\
\hline 4 & 4 & 19.05 & 10 \\
\hline 5 & 2 & 9.52 & 0 \\
\hline 6 & 0 & 0 & 0 \\
\hline 7 & 0 & 0 & $\sum \mathrm{FX}=56$ \\
\hline Total & $\mathrm{N}=21$ & & \\
\hline
\end{tabular}

The Table No 2 represent the number of Nepalese co-operative organizations practicing one or more management accounting tools. It revealed that in average 3 management accounting tools were used in co-operative organization. It is also revealed that $38.10 \%$ of co-operative organization use less than average number of management accounting tools. Altogether 3 tools were used by $33.33 \%$ co-operative organization and $28.57 \%$ other co-operative organization use more than the average no. of management accounting tools the main reasons given for not practicing of these tools contained that, majority of the respondents opined that management accounting is related to manufacturing and trading business rather than service industry like co-operation organization. Some other respondents opined that these tools are not practiced in Nepalese co-operative organization due to lack of knowledge or no information about the tools, lack of experienced human resources and high cost/quite expensive.

The Department for Budget Preparation in Nepalese Co-operative Organization

Nepalese co-operative organization prepare their budget through many departments like, finance, planning, budget committee, outside expert and other which is given below table:

Table 3

\begin{tabular}{|c|l|c|c|c|}
\hline S.N. & $\begin{array}{l}\text { Budget Preparing } \\
\text { Department }\end{array}$ & $\begin{array}{c}\text { No. of } \\
\text { Sample }\end{array}$ & $\begin{array}{c}\text { no of Co-operative } \\
\text { Organizations }\end{array}$ & Percentage \\
\hline 1 & $\begin{array}{l}\text { Finance } \\
\text { Department }\end{array}$ & 21 & 20 & 95.24 \\
\hline 2 & $\begin{array}{l}\text { Planning } \\
\text { Department }\end{array}$ & 21 & - & - \\
\hline 3 & Budget Committee & 21 & 3 & 14.29 \\
\hline 4 & Outside Expert & 21 & - & - \\
\hline 5 & Others & 21 & 2 & 9.52 \\
\hline
\end{tabular}




\section{The Journal of Madhyabindu Multiple Campus, Vol. 6, No. 1, 2021}

The Table No 3 present the budget preparing system practiced in Nepalese Co-operative Organization. It co-operative organization of Nepal prepare their budget through finance department, 14.29 percent prepare their budget through budget committee and only 9.52 percent of them prepared their budget jointly by the head office and chief and chief officer of the co-operative organization. it is also seen in the table that no Nepalese Co-operative Organizations made the budget through their planning department and no co-operative organization hires outside experts to prepare their budget.

\section{Types of Budget Practiced in Nepalese Co-operative Organization}

In Nepalese context co-operative organization mainly three types of budget practices which are master budget, cash budget and operational budget. They are shown in below table:

Table 4

\begin{tabular}{|c|l|l|c|c|}
\hline S.N. & Types of Budget & $\begin{array}{l}\text { No. of } \\
\text { Sample }\end{array}$ & $\begin{array}{l}\text { No of practicing } \\
\text { cooperative Organization }\end{array}$ & Percentage \\
\hline 1 & Overall Master Budget & 21 & 12 & 57.14 \\
\hline 2 & Cash Budget Only & 21 & 2 & 9.52 \\
\hline 3 & Operational Budget & 21 & 6 & 28.57 \\
\hline 4 & Others & 21 & 0 & 0 \\
\hline
\end{tabular}

The Table No 4 shows the type of budget practiced by the co-operative organization of Nepal. It is seen that, nearly 57.14 percent of Nepalese Co-operative Organization practiced over all master budgets, 28.57 percent of them practice operational budget and only 9.52 percent of them practiced cash budget.

\section{Major Finding}

On the basis of the above comprehensive analysis of data and information, the following findings have been identified:-

i. While analyzing the application of management accounting tools practiced in Nepalese co-operative organization for planning, controlling and decision making, it was found that Ratio Analysis, Cash flow statement and capital Budgeting are widely practiced representing $71.43 \%, 66.67 \%$ and $47.62 \%$ respectively out of total 21 cooperative organization ii. Out of total sample number of co-operative organization $38.10 \%$ did not meet the average number of tools used, while $33.33 \%$ met the exactly average number of management accounting tools and remaining $28.57 \%$ organizations were practiced more than average number of management accounting tools.

iii. It is found that Finance Department prepared the budget in $95.24 \%$ of the co-operative organization. In $14.29 \%$ co-operative organization, Budget committee prepared the budget. In $9.52 \%$ of the co-operative organization, head office and chief executive officer made the budget for the organization.

iv. It is found that Finance department prepared the budget in $95.24 \%$ of the co-operative organization. In $14.29 \%$ co-operative organization, Budget committee prepared the budget. In $9.52 \%$ of the co-operative organization, head office and chief executive 


\section{Management Accounting Practices in Nepalese Co-operative Organizations}

officer made the budget for the co-operative organization.

v. In average one system was applied to prepare budget in each co-operative organization of Nepal, out of total co-operative organization $95.24 \%$ use one system for the preparation of budget. And $4.76 \%$ of co-operative organization have not applied any systems for preparing its budget.

vi. Whit regard to functional budget, $57.14 \%$ Nepalese co-operative organization prepare over all master budget, $28.57 \%$ of Nepalese co-operative organizations prepare operational budget. And only $9.52 \%$ of the co-operative organization prepare cash budget. Hence, It is seen that, majority of the co-operative organization practices the overall master budget.

\section{Conclusion and Discussion}

Management is an art of getting things done through other people by using the means of planning, organizing, staffing, directing and controlling to achieve organizational goal effectively and efficiently in a dynamic environment. Management has to concentrate its activities on the mobilization of organization's availed scarce resources in effective and efficient manner. Managerial skills and competencies are keys for organization. It is equally important for the organization no matter how it is commercial or non-commercial and public or private.

Nepalese Co-operative Organizations are one sector of economy as they safeguard against the risk that exists in business as well as in human daily life. Every co-operative organization has limited resources which should be mobilized in such a way that it can get its best. For better utilization of resources, different tools and techniques have been developed. Among them, management accounting tools have proved beneficial in different aspects of managerial activities.

Management accounting is one of the important disciplines of accounting. It is the branch of accounting whose main objective is to help managers in overall managerial activities by providing various information and helping in planning, controlling and decision making. Management accounting acts as a strategic business partner in support of managerial role in rational decision making.

Cost segregation, Cost-volume profit analysis, Responsibility Accounting, Cash flow statement, standard costing, Zero-based Budgeting are the major tools of management accounting. Whether the Nepalese Co-operative Organizations are getting benefits from those management accounting tools or not? To identify these facts, this research was conducted.

The study was done with an objective to examine the present practice of management accounting tools in the Co-operative Organization, and to identify the area management accounting tools can be applied to strengthen the financial position of co-operative organization. With respect to this objective, the present research has explored the real position of applicability of management accounting tools in Nepalese co-operative organization.

As per the nature and demand of the study, survey type research design was adopted with descriptive and analytical approach. The research is mostly based on primary source of information. Secondary source of data was also used. He data was collected from the respective I co-operative organization by distributing structured questionnaire. The raw data was applied to analyze and interpret the findings. The statistical tool chi-square $\mathrm{x} 2$ was used to test the assumptions.

Management accounting is a new discipline and still in developing stage in the context of modern business organization. Different types of management accounting tools and techniques are evolving as a new dimension to facilitate the management to perform the better managerial jobs covering from planning to control. These various types of management accounting tools and techniques are taught in the university college. However, they are 


\section{The Journal of Madhyabindu Multiple Campus, Vol. 6, No. 1, 2021}

found not fully practiced in Nepalese co-operative organization. It is the realities of gap between the theory and practice.

On the basis of data analysis, it can be concluded that management accounting tools like Capital Budgeting, Ratio Analysis, and Cash Flow Statement were widely practiced in Nepalese cooperative organization. Similarly, Cost-volume-profit Analysis, Responsibility Accounting, Activity Based budgeting were moderately practiced. The other management accounting tools like standard costing and Zero-based budgeting were in practiced by few Nepalese co-operative organization Accordingly, the main reason for not practicing zero-base budgeting was lack of proper knowledge about the tool.
Finally, it can be concluded that the cooperative organization of Nepal are in infant stage with respect to the application of modern management accounting tools. Yet, they are trying to adopt such tools and techniques to cope with the future expected opportunities and challenges to be faced due to the accession of globalization.

The management accounting tools and techniques in every type of organization are not the optional but also the compulsion in the better performance of the entity. Management accounting plays a significant role for every type of business organization. It provides the key ideas, guidelines and strategies to the management for better performance of managerial functions.

\section{References}

Acharya, N. (2013). Management Accounting Practice in Nepalese Public Enterprises, submitted to Shankerdev Campus, TU.

Agrawal, G.R. (2009). Dynamics of Business Environment in Nepal.Kathmandu: M.K. Publisher and Distributors

Bajracharya, P., Ojha K.P., Goet, J. and Sharma, S. (2009), Managerial Accounting: Nepalese Perspective, Kathmandu: Asmita Book Publishers and Distributors.

Baral, L.R. (2014). Management Accounting Practices in Nepalese Commercial Bank of Nepal, submitted Shanker Dev Campus, TU

Batty, J., (2009). Management Accounting, London: ELBS and Macdonald and Evans Ltd.

Drury, C. (2011). Management and Cost and Management Accounting, London:Business Press, Thomson Learning.

Fago, G., Subedi, D.P. and Gyawali, A. (2003). Management Accounting.Kathmandu: Buddha Academic Publishers \& Distributors Pvt. Ltd.

Garrison, R.H. (2006). Managerial Accounting, Texas: Business Publication Incorporation.

Gupta, B.(2015). A Comparative Study on Profit Planning in Manufacturing and Non-Manufacturing Public Enterprises of Nepal, submitted Nepal Commerce Campus, TU.

Gupta, S.P. (2007). Managerial Accounting, New Delhi: Prentice Hall of India Pvt.

Ltd.

Hilton, R.W. (2010). Managerial Accounting, New York: McGraw-Hill

Horngreen, C.T. (2008). Introduction to Management Accounting, New Delhi: $\quad$ Prentice Hall of India Ltd. 
Management Accounting Practices in Nepalese Co-operative Organizations 37

Jain, S.P. \& Narang, K.L. (2008). Advanced Accounting. New Delhi: Kalyani Publishers.

Neupane, K.B. (2012). Management Accounting Practice in Joint Ventures Banks of Nepal, submitted to Centre Department, TU.

Khan, M.Y. and Jain, P.K. (2010). Management Accounting, New Delhi: Tata McGraw-Hill Publishing Co.Ltd.

Paul, S.K. (2004). Management Accounting, Calcutta: New Central Books Agency Pvt Ltd.

Sharma, S. (2011). Management Accounting Practices in Listed Companies of Nepal, submitted Shankerdev Campus, TU.

Shrestha, N.K. (2007). Management Accounting, New Delhi: Tata McGraw Hill Publishing Co.Ltd.

Singh, Y.M. Ojha, K.P. and Acharya, C.(2004). Cost and Management Accounting, Kathmandu: Buddha Academic Publishers and Distributor Pvt.Ltd. 